\title{
EXTENSIVE READING FOR TRANSLATION: ACQUIRING VOCABULARY FOR BETTER RENDITION
}

\author{
I Gusti Ngurah Agung Wijaya Mahardika \\ Institut Hindu Dharma Negeri Denpasar \\ wijayamahardika@gmail.com
}

\begin{abstract}
Errors in translation stems from numerous sources, yet one of the most common sources of the errors is the lack of vocabulary mastery. Therefore, it is imperative for aspiring translators to increase their vocabulary mastery. This article proposed extensive reading through the implementation of book club in Translation class to increase students' vocabulary. The rationale for the book club as well as the details of the implementation are discussed herein.
\end{abstract}

Keywords: translation, book club, extensive reading

\section{INTRODUCTION}

One of the most common errors made by students and novice translator is the failure to employ the correct lexical equivalence to convey the appropriate meaning from the Source Language (SL) to the Target Language (TL). This kind of error is both common, i.e. happen across language pair, and also very dangerous since it highlights students' lack of vocabulary mastery (Wongranu, 2017; Yousofi, 2014). The following is an example of the errors made by some Indonesian students in translation.

\begin{tabular}{|l|l|l|l|}
\hline $\begin{array}{l}\text { Source } \\
\text { Language }\end{array}$ & $\begin{array}{l}\text { Students' } \\
\text { Rendition }\end{array}$ & Explanation & $\begin{array}{l}\text { Proposed } \\
\text { Rendition }\end{array}$ \\
\hline $\begin{array}{l}\text { Ketinggian } \\
\text { gelombang } \\
\text { di laut } \\
\text { dalam } \\
\text { hanya } \\
\text { sekitar 1 } \\
\text { meter. }\end{array}$ & $\begin{array}{l}\text { The high } \\
\text { of the } \\
\text { wave is } \\
\text { just } \\
\text { around 1 } 1 \\
\text { meter }\end{array}$ & $\begin{array}{l}\text { "Ketinggian" } \\
\text { should have } \\
\text { been } \\
\text { translated } \\
\text { into "height" } \\
\text { (N) instead of } \\
\text { 'high" (Adj) }\end{array}$ & $\begin{array}{l}\text { The } \\
\text { height of } \\
\text { the wave } \\
\text { in deep } \\
\text { sea is just } \\
\text { about 1 } \\
\text { meter }\end{array}$ \\
\hline $\begin{array}{l}\text { kan } \\
\text { jatuhnya }\end{array}$ & $\begin{array}{l}\text { The } \\
\text { decay } \\
\text { and the } \\
\text { victim }\end{array}$ & $\begin{array}{l}\text { "Damages" } \\
\text { and casualties" } \\
\text { are more }\end{array}$ & $\begin{array}{l}\text { Damages } \\
\text { and } \\
\text { casualties }\end{array}$ \\
\hline
\end{tabular}
employing the appropriate lexical equivalence to convey the meanings from the source language, even when the words are simple, non-genrespecific words. This problem is most likely to be caused by lack of exposure to written and verbal text in the target language. Students simply do not know the appropriate lexical equivalence required to deliver a good rendition. For aspiring translator and even for general language learners, vocabulary mastery is an important aspect of language learning. Increased vocabulary capacity will improve a learner's ability to comprehend linguistic inputs and at the same time it will enhance the learners' output in 
the target language. In translation work, a translator with rich vocabulary capacity will be able to deliver a native like rendition of the text being translated.

As can be seen from the above example which was taken from Indonesian undergraduate students majoring in English education, it is clear that said students need to increase their vocabulary capacity. Mistranslation of a specific or genrerelated term may be caused by lack of exposure to the specific genre, however, using the noun instead of the adjective form of a common everyday word such as "height" shows that the students have low vocabulary capacity. The basic and yet most effective remedy to this problem is simply an improvement of the students' vocabulary size. Scholars have different ideas on the number of vocabularies required by a person to be considered as having native-like language proficiency. Scholars, however, tend to agree on 2000 words baseline as the requirement for basic oral conversation or basic reading task (Blachowicz and Fisher, 2000; Schmitt, 2008; Nutall, 1996). Schmitt further predicts that to be able to have academic success, a learner has to master close to 10,000 words; and 15,000 words to achieve native-like language proficiency (Schmitt, 2008). Translation work, naturally, require more than just the 2000 words baseline, maybe even coming close to the 10,000 words mark.

In order to achieve the required size of vocabulary, scholars contend that incidental vocabulary learning through Extensive reading will be more beneficial for the students' vocabulary improvement compared to intentional vocabulary learning in the classroom, i.e. learning a list of vocabulary and constructing sentences using the words in the list (Blachowicz and Fisher, 2000; Lee \& Mallinder, 2007). Similarly, Akhmad (2012) found that students acquired vocabulary though incidental learning significantly better compared to intentional learning. Students who were exposed to 50 new vocabulary through incidental learning achieved perform better in final test where $50 \%$ of the students taught using incidental method scored $80 \%$, compared to only $10 \%$ of the students taught using intentional method who scored $80 \%$ in the final test.

One of the most widely implemented incidental vocabulary learning is the extensive reading. Extensive reading will help students acquire vocabulary through incidental vocabulary learning, a process where a person learns a word through repeated encounters with said word. After repeated encounters with the word in different contexts, said person will form meaning, collocation as well as word connection (Webb, 2007). Extensive reading can be implemented easily and requires only reading materials, which might be a bit of a problem in the old analog day, but a simple problem to solve in today digital era, where books no longer exists in printed copy only. The availability of the books truly propels extensive reading into a prominent position in language learning, since it 
has been proven to be very beneficial for language learners.

Extensive reading has been the subject of numerous studies, especially in relation to vocabulary development and foreign language learning in general. Extensive reading has been proved to improve students' attitude towards English reading and learning and improves students writing and grammar competency (Mason, 1997). In a 2017 study on a Korean University EFL students, the extensive reading approach even provides better performance gain in the area of reading comprehension, reading rate of speed, as well as vocabulary improvement, compared to intensive reading approach (Suk, 2017; Webb \& Chang, 2015). Suk (2017) studied the four intact classes of EFL students, the students were divided into two groups, the control and the experimental group. The control group was exposed to 100 minutes of intensive reading instruction, meanwhile the experimental Group was exposed to 70 minutes intensive reading instruction and 30 minutes extensive reading instruction. The result of the study shows that the experimental group performed significantly better compared to the control group across all three variables, namely reading comprehension, reading rate, and vocabulary acquisition.

Extensive reading has also proven to be effective in improving students' ability to learn new vocabulary, including the spelling, meaning and grammatical rules of the vocabulary usage (Pigada \& Schmmit,
2006). Pigada \& Schmmit studied a Greek student who learned French as a foreign language. The participant was exposed to four reading materials amounting a total of 228 pages and 30.000 words. The goal of learning was the introduction of the target words which consisted of 70 nouns and 63 verbs amounting to a total number of 133 words. The study was conducted for one moth where the participant read one book per week. By the end of the study, they found that there is a substantial word learning across three different types of word knowledge, spelling, meaning, and grammatical rules. From these types of knowledge, the most affected was, from highest to lowest order of improvement, spelling, meaning, and grammatical rules. The results of these studies show that extensive reading can effectively improve more than just students' vocabulary size, thus making it a perfect approach for students struggling with vocabulary mastery in translation.

\section{DISCUSSION}

Extensive reading can be defined as one's involvement in pleasure on a wide range of linguistically or culturally relevant and appropriate subjects (Lee \& Mallinder, 2007). The definition above stipulates that the reading must be done by 1) exposing the students with a wide range of subjects, i.e. topics, which are appropriate for the students in terms of linguistic and cultural content, and 2) in a pleasurable way, i.e. non-threatening condition and 
provide the students with a sense of enjoyment.

To be successful in conducting extensive reading approach for their students, teachers must follow extensive reading principles which will prompt the students to have a pleasurable reading experience over a wide range of appropriate subjects. Day and Bamford define the following principles for teaching extensive reading.

1. The reading material is easy. The text must be well within the students reading competence with several difficult or new words per page.

2. The material must cover a wide range of topics. The reading materials must come in varying forms such as books, magazine, articles, blog pages, and cover different topics ranging from fiction, non-fiction, economics, history, science, to comedy.

3. Students choose what they want to read. Students must be encouraged to choose their own reading materials which will be interesting for them and to their liking.

4. Students read as much as possible. Students must be given time to read on their leisure, therefore there is no set amount of time for the students to do their reading. Scholars, however, agreed that one book or text per week is the minimum amount of reading required to instill the habit of reading in the students.
5. The purpose of reading usually revolves around enjoyment, information, and general comprehension. The aim of extensive reading focuses more on personal reading experience instead of any academic objectives

6. Reading experience is the reward in its own. Extensive reading is not to be followed by comprehension questions, but extensive reading activities such as reporting about the reading experience instead of their comprehension.

7. Reading speed is usually faster than slower. When students like what they read, they read faster. When students are accustomed to read extensively, they will eventually enter the cycle of read faster, read more, understand better, enjoy reading, read faster, and so the cycle continues.

8. Reading is individual and silent. Students must be given the time and space to read by themselves, as they like it, for themselves at home; or at school along predetermined time allocated just for reading.

9. Teacher orients and guide the students. The teacher must introduce the extensive reading approach to the students, including the fact that the aim of reading is not comprehension, and the core idea is to read not to answer the 
post-reading question for there will be no such questions.

10. The teacher is a role model. In the wise word of Nutall (1996), "reading is caught, not taught". Teachers themselves must be an avid reader and become the role model for the students. (Day and Bamford, 2002; Day, 2015)

Based on the above principles, a teacher of translation course must also incorporate extensive reading as part of the course. Due to the fact that Translation course main learning objective is to teach and train university EFL students to translate texts from Bahasa Indonesia to English and vice versa, the extensive reading approach must not interfere with the main learning objective. The only way to do this is by conducting the extensive reading in a semistructured way, i.e. having a predesigned reading list while still maintaining the principles of extensive reading. This can be achieved by setting up a book club (Marusic, 2006), and conducting the club meeting outside the time allotted for the translation course.

As delineated by Day and Bamford's principles, the teacher must start the book club at the same time the course starts. The teacher must explicitly explain to the students the aim of the book club, the reading list, the post-reading activities, as well as the explanation that students will never be scored based on their reading comprehension and that the post reading activities are aimed at

expressing and discussing students, feeling and maybe questions or opinion about their reading instead of their comprehension of the reading material.

To have a more streamlined and focused discussion, the teacher must prepare the reading list beforehand, and explain to the students that they have one week for each reading material to be read. The reading list should consist of a variety of genres and topics. It is a good idea to start the book club with a short reading such as a short story and then gradually move to longer ones. When selecting longer books, Teacher can always have some of the students to form a pilot group to select the book. The pilot group can use the 5 fingers rule, in which the pilot group one a random page of the book and count using their fingers for every unknown word in a page. If it has more than 5 unknown words per page, it is considered too difficult and move to the next book until they have found the book with five or less unknown words (Day, 2015; Jacobs, 2014). Nevertheless, when the teacher considers the students to have advanced mastery of English the book club can start with a short book such as Robert Louis Stevenson's The Treasure Island instead of a short story and then moves into longer book.

It is also a good idea to put translated works into the list of readings, such as the English version of Alexandre Dumas' the Three Musketeers; This Earth of Mankind, the English translation of Pramoedya 
Ananta Toer's Bumi Manusia; or Never The Twain, the English translation of Abdoel Moeis' Salah Asuhan. The inclusion of the translated works from the students L1 also opens up a new avenue in teaching translation, students can later compare the differences between the original and the translated version of the book. Regardless of the reading selections, one thing that everyone must keep in their minds is that the aim of the book club is to read the materials for the enjoyment of reading itself, not oriented on the comprehension of the reading materials. The following is an example of the reading list which can be used by the teacher in an extensive reading approach.

\begin{tabular}{|c|c|c|c|}
\hline Title & Author & Genre & Theme \\
\hline $\begin{array}{l}\text { Tonight's Pink } \\
\text { Moon Won't } \\
\text { Actually Be A } \\
\text { Pink Moon. }\end{array}$ & $\begin{array}{l}\text { Rachel } \\
\text { Feltman }\end{array}$ & $\begin{array}{l}\text { Science } \\
\text { Article }\end{array}$ & Science \\
\hline $\begin{array}{l}\text { How the } \\
\text { Elderly Lose } \\
\text { Their Rights }\end{array}$ & Rachel Aviv & $\begin{array}{l}\text { News } \\
\text { Article }\end{array}$ & Politics \\
\hline Mary Toft & - & $\begin{array}{l}\text { Wikipedia } \\
\text { Entry }\end{array}$ & Hoax \\
\hline $\begin{array}{l}\text { The Amazing } \\
\text { Dinosaur } \\
\text { Found } \\
\text { (Accidentally) } \\
\text { by Miners in } \\
\text { Canada }\end{array}$ & $\begin{array}{l}\text { Michael } \\
\text { Greshko }\end{array}$ & $\begin{array}{l}\text { News } \\
\text { Article }\end{array}$ & Anthropology \\
\hline $\begin{array}{l}\text { My Father } \\
\text { Spent } 30 \text { Years } \\
\text { in Prison. Now } \\
\text { He's Out. }\end{array}$ & $\begin{array}{l}\text { Ashley C. } \\
\text { Ford }\end{array}$ & $\begin{array}{l}\text { Personal } \\
\text { Story }\end{array}$ & Life \\
\hline $\begin{array}{l}\text { Chicken Soup } \\
\text { for the College } \\
\text { Soul }\end{array}$ & $\begin{array}{l}\text { Jack } \\
\text { Canfield }\end{array}$ & Book & Motivation \\
\hline $\begin{array}{l}\text { Rich Dad Poor } \\
\text { Dad }\end{array}$ & $\begin{array}{ll}\text { Robert } & \mathrm{T} \\
\text { Kiyosaki } & \\
\end{array}$ & Book & Economics \\
\hline $\begin{array}{l}\text { The Treasure } \\
\text { Island }\end{array}$ & $\begin{array}{l}\text { Robert } \\
\text { Louis } \\
\text { Stevenson }\end{array}$ & Novel & Adventure \\
\hline Animal Farm & $\begin{array}{l}\text { George } \\
\text { Orwell }\end{array}$ & Novel & Politics/Fable \\
\hline $\begin{array}{l}\text { The Old Man } \\
\text { and The Sea }\end{array}$ & $\begin{array}{l}\text { Ernest } \\
\text { Hemingway }\end{array}$ & Novel & Literature \\
\hline $\begin{array}{l}\text { The Sands of } \\
\text { Time }\end{array}$ & $\begin{array}{l}\text { Sidney } \\
\text { Sheldon }\end{array}$ & Novel & Light Fiction \\
\hline $\begin{array}{l}\text { Anne Frank: } \\
\text { The Diary of a } \\
\text { Young Girl }\end{array}$ & Anne Frank & Novel & History \\
\hline The Firm & $\begin{array}{l}\text { John } \\
\text { Grisham }\end{array}$ & Novel & Law \\
\hline Micro & $\begin{array}{l}\text { Michael } \\
\text { Crichton }\end{array}$ & Novel & Science \\
\hline $\begin{array}{l}\text { Who Ordered } \\
\text { This Truckload } \\
\text { of Dung? }\end{array}$ & Ajahn Bram & Book & Spiritual \\
\hline
\end{tabular}


After setting out the reading list, the teacher can now inform students about the books that they are required to read so the students can find the books. It would be ideal if the teacher can supply the reading altogether, so the students can focus more time on reading than on searching for the books. Considering Day and Bamford's principle that "reading speed is usually faster than slower", students who have been hooked by the reading activity may even continue to the next book after they have finished with the week's book. The students can read from the first week and then have a book club meeting session the week after. Therefore, during the first week students will read the first book, and they will discuss the reading experience on the second week. After the discussion, they will start with the second book which will be discussed in the third week, and so on.

During the meeting session, the teacher guides the discussion regarding the reading experience and the reading material itself, but should not test students' comprehension of the reading material. The teacher can lead the discussion by asking about students reading experience, the students' response to the reading, the character they like or dislike and their reasons, their favorite part of a novel of a story, memorable line or event in a story. This line of questions will help students to think about their reading experience and not threaten them the way a reading comprehension test would. The teacher, however, must pay close attention to the dynamic of the book discussion, since as with any form of discussion, there is always the probability of dominating participants and escaping participants. Teachers must try their best to involve all the students and provide a space and time for each student to talk about their reading experiences. Some students may need more prompting than others, while some students may need some slowing down prompt from the teachers.

By the end of the $16^{\text {th }}$ week, students would have read 15 books and these books would have supplied students with not only new vocabulary but also cultural knowledge as well as, hopefully, a healthy reading habit. These are the things a translator would need in his or her trade because in translating cultural understanding of the target language will be very helpful for the translator in delivering meanings accurately. Furthermore, even when students did not pursue any translating career, a healthy reading habit is a very beneficial habit to have not for academic life but also for daily life since reading can be an act of information seeking and pleasure seeking at the same time.

\section{CONCLUSION}

Empirical and theoretical background have provided reasons to believe that extensive reading approach may increase students' vocabulary mastery and improve the size of their vocabulary through incidental vocabulary acquisition. Therefore, in order to improve 
students' competency in translating teacher must strive to increase the students' vocabulary size by implementing extensive reading approach when teaching translation. In implementing the extensive reading approach by conducting a book club, for example, the teacher should closely observe its principles and incorporate them into their teaching practice. Such incorporation may require having separate meetings for the book club. The implementation of extensive reading may result in additional burden for both the students and the teachers, however, previous studies have shown that the benefit outweighs the extra burden making extensive reading a very attractive approach to be implemented by teachers

\section{REFERENCES}

Ahmad, J. (2012). Intentional vs. Incidental Vocabulary Learning. ELT Research Journal, 1(1), 71-79.

Blachowicz, C., \& Fisher, P. (2000). Vocabulary instruction. In M. L. Kamil, P. B. Mosenthal, \& P. D. Pearson (Eds.), Handbook of Reading Research. Volume III (pp. 503-517). Mahwah, NJ: Erlbaum Assoc.

Day, R. R. (2015). Extending Extensive Reading. Reading in a Foreign Language, 27(2), 294-301.

Day, R., \& Bamford, J. (2002). Top Ten Principles For Teaching Extensive Reading. Reading in a Foreign Language, 14(2), 136-141.

Jacobs, G. M. (2014). Selecting Extensive Reading Materials. Beyond Words, 2(1), 116-131.
Lee, H., \& Mallinder, M. (2007). Role of Extensive Reading in EFL Vocabulary Development: Review and Recommendation. The English Teacher, XL, 145-163.

Marusic, M. (2006). Book Clubs and Extensive Reading in A Predominantly Media-Oriented World: Reflections on an Experience in Croatia. Reflections on English Language Teaching, 5(2), 87-112.

Mason, B., \& Krashen, S. (1997). Extensive Reading in English as A Foreign Language. System, 25, 91-102.

https://doi.org/10.1016/S0346251X(96)00063-2

Nuttall, C. (1996). Teaching Reading Skills in A Foreign Language (2nd Ed). Oxford: Heinemann.

Pigada \& Schmitt, M. (2006). Vocabulary Acquisition from Extensive Reading: A Case Study. Reading in a Foreign Language, 18(1), 1-28.

Schmitt, N. (2008). Review Article: Instructed Second Language Vocabulary Learning. Language Teaching Research, 12(3), 329-363.

Suk, N. (2017). The Effects of Extensive Reading on Reading Comprehension, Reading Rate, and Vocabulary Acquisition. Reading Research Quarterly, 52(1), 73-89.

https://doi.org/10.1002/rrq.152

Suk, N. (2017). The Effects of Extensive Reading on Reading Comprehension, Reading Rate, and Vocabulary Acquisition. Reading Research Quarterly, 52(1), 73-89. 
https://doi.org/10.1002/rrq.152

Webb, S. (2007). The effects of repetition on vocabulary knowledge. Applied Linguistics, 28(1), $\quad 46-65$. https://doi.org/10.1093/applin/a ml048

Webb, S., \& Chang, A. C. S. (2015). Second language vocabulary learning through extensive reading with audio support: How do frequency and distribution of occurrence affect learning? Language Teaching Research, 19(6), 667-686. https://doi.org/10.1177/13621688 14559800

Wongranu, P. (2017). Errors in translation made by English major students: A study on types and causes. Kasetsart Journal of Social Sciences, 38(2), 117-122. https://doi.org/10.1016/j.kjss.201 6.11 .003

Yousofi, N. (2014). Describing the Errors in the Translations of Iranian Novice English Translators. Procedia - Social and Behavioral Sciences, 98, 19521958.

https://doi.org/10.1016/j.sbspro. 2014.03.628 